\title{
Sexist Hate Speech as Subjectivation: Challenges in Media Education
}

\author{
Britta Hoffarth
}

\begin{abstract}
This chapter is dedicated to exploring the practice of sexism-in the sense of sexist hate speech-in digital media and its discursive relationship to theories of subjectivation and education. While I do not approach the issue via the concept of discourse in a formal analytical sense, I reference a Foucauldian view of language drawing on theories of discourse and identifying language and speaking as instruments of power and knowledge. After surveying the current state of digitisation and media education, I will use examples of sexist hate speech to examine the relevance of the gendered orders in force in media and beyond and illuminate a gap in theories of media education in terms of their neglect of the analysis of power relations.
\end{abstract}

Keywords Sexist hate speech $\bullet$ Online $\bullet$ Subjectivation $\bullet$ Media education

B. Hoffarth $(\bowtie)$

Institut für Erziehungswissenschaft, Universität Hildesheim, Hildesheim, Germany

e-mail: hoffarth@uni-hildesheim.de

(C) The Author(s) 2022

69

P. Bettinger (ed.), Educational Perspectives on Mediality and

Subjectivation, Palgrave Studies in Educational Media, https://doi.org/10.1007/978-3-030-84343-4_4 


\section{Digitisation and Issues of Media Education}

Techno-sociological discourses are now referring to digital media as the fourth narcissistic affront to "anthropocentric humanism" (DeuberMankowsky, 2007, p. 278) and pointing to a "border between the human and the technological that has become fragile" (Eickelmann, 2017, p. 19). ${ }^{1}$ At the outset of the internet age around the turn of the millennium, it was still challenging to adequately evaluate these new media of digital communication against the backdrop of established media cultures, such as television and print media. The challenge today, by contrast, appears to lie in examining the specifics of digital communication beyond its everydayness, its ubiquity and therefore, to an extent, its invisibility, read in the frame of Bourdieu's concept of the doxa. ${ }^{2}$ However, this effect of the digital space becoming 'invisible', in the sense of its de-thematisation and its disappearance into the self-evident, only holds for those who do not struggle to disseminate their own content, who have access to technology, stylistic devices, and hegemonic forms of representation. In this context, the term 'digitisation' describes not only the quantitative spread of digital technologies, but also a node in the discourse of technological progress, which at the same time stands for forms of social and cultural transformation without being able to explicate them. It is a fundamental paradox of social media that the conception of access to the internet, both as a knowledge resource and as a medium of self-representation, as a basic human right stands alongside the simultaneous symbolic regulation of participation in digital spaces, as is apparent in hate speech and other phenomena.

Within these to a degree contradictory considerations and alongside current studies on media use (Bertelsmann Stiftung, 2019; Capurro, 2017; Dengel, 2018; Kaspar et al., 2017; Kerres, 2018), current considerations from the educational field on the significance of digital media to adolescents engage with both the risks and the potential of digital practices. It is a discussion that emerges on at least two levels: in the continuation of established discourses in media education, and in education studies' novel centring of media in the consideration of matters around political education. While much discussion of digitisation in pedagogy relates to matters of media literacy (Gesellschaft für Medienpädagogik und Kommunikationskultur in der Bundesrepublik Deutschland e. V. (GMK), 2013; Mitgutsch, 2009), I propose to take a distinct approach, exploring the phenomenon in terms of education theory, with an emphasis on social critique and the analysis of power relations. 
The exploration of facets of education theory (Bildungstheorie) ${ }^{3}$ within media education, as inspired by the discipline of media studies, is a relatively recent phenomenon. The reverse preoccupation, of education theory with matters of media has a tradition; this said, media and their associated cultures remain fairly marginal in general education studies (Sesink, 2014). The task of addressing the relationship between media and education seems all the more urgent for the current development of the new and constantly renewing media into a "trouble spot", as Sesink (ibid., p. 12) puts it. Referring to Marotzki and Jörissen, Iske proposes to systematically meet current challenges with a "structural media education" that is not based on representational media, but on the phenomenon of 'mediality', which abstracts from media phenomena and media types and focuses on overarching aspects of form and structure (2014, p. 4). This definition conceives of mediality as an anthropological moment, as a constitutive "(a) prerequisite for symbolism, (b) structural condition of concrete (cultural-historical) forms of articulation and thus (c) as a structural condition in education theory for the construction of relationships with the self and with the world" (Jörissen, 2014, p. 503). Iske, who identifies Humboldt's theory of education as the starting point of this approach to media education, notes the difficulty of determining the extent to which "the conventional understanding of education has to be reformulated in view of changes in social conditions" $(2014$, p. 7$)$. We might formulate this issue, and the theoretical ambition inherent to it, even more radically thus: While we may safely assume that translations of neo-humanist concepts of education already exist, it seems necessary to determine more precisely what the concept of 'social conditions' actually refers to empirically, in order to access the (technical) historical and socio-structural contexts of reflection on education, specifically media education. Gendered orders and their immanent violence are one facet of social conditions which this chapter will explore, aiming to illuminate their significance for those growing up in both gendered and digitised societal contexts.

While they take traditional educational concepts from the Enlightenment into account and thus contrast approaches to media literacy (a set of acquirable skills )with an idea of education that calls into question overly linear ideas of the transmission of knowledge, current concepts of media education could be accused of implying a relatively unproblematic notion of education. We may concur with Alfred Schäfer in essentially assuming that education does not occur as a process of linear transformation, but instead is accompanied by various disruptions (Schäfer, 2019) that are, as 
we will go on to note, closely linked to the problem of representation. It appears, therefore, that we are in need of a concept of media education that considers both the political implications of social differences in how individuals engage with media and the fragility of processes both of education and of the reception of media content.

This chapter will explore the phenomenon of sexist online hate speech in the light of feminist media studies, illustrating the various facets of gender-based violence in online environments and its inherence to these settings. It will subsequently proceed to develop a theoretical framework for examining the phenomenon, discussing the relationship between representation and subjectivation. Concluding, I will consider this framework's productivity for rethinking issues of media education.

\section{Sexist Hate Speech Online}

Sexist discrimination encompasses structural and individual practices of discrimination on the basis of gender. This discrimination does not, as the term might suggest, refer only to the topos of sex, but can occur towards members of both the female and the male sex; a diversity, persistence and sharpness, however, is distinctly observable in sexist discrimination towards femininity: "everyday sexism exemplifies male entitlement" (Jane, 2017a, p. 1). Döring and Mohseni (2018) note that current studies on male domination in social media demonstrate the general abundance of negative and hateful feedback in online communication and that female participants in particular face substantially greater volumes of negative and particularly sexualising and cruel comments on their appearance than do male participants (ibid., p. 511). We can cite Eickelmann in defining internet hate speech as a form of "mediatised" $(2017$, p. 21$)$ disregard, including defamation, insults, death and rape threats, which function as a vengeful or controlling imposition of impending violence and a punitive sanction applied to public media appearances marked as feminist or even just female. In both the mass media and social convergence media with user-generated content such as YouTube and Whatsapp, media stagings of femininity appear to be particularly conflictual in their susceptibility to social sanction; for example, young girls who send nude photos of themselves in the course of so-called sexting (cf. Bedor, 2015; Amundsen, 2019; Döring, 2014) may suffer severe loss of social reputation if they are subsequently the subject of a 'revenge porn' attack, and suicides have been documented in this context (cf. Eickelmann, 2017). The dilemma facing female 
adolescents here consists in the contradictory social demands imposed on them; the expectation of self-performance of sexual attractiveness clashes with the requirement of modesty and self-restraint and the oftenly punitive response to any self-confident or self-determined bodily displays. Victim-blaming is closely linked to the experience of online harassment (cf. Lumsden \& Morgan, 2017). There appears here an interpretation of girls' sexual self-determination as a threat to a socially desirable concept of femininity. In other words, sexist bullying or hate speech in digital media always refer back to power relations that already possess social significance outside media spaces. The social sanction falls upon girls' offensive (in both senses of the word) presentation of their sexuality, not the illegal publication of the images. The common variants of sexist hate speech online, such as threats of rape or death and doxxing (the publication of personal data such as the victim's home address), are both individual attacks and massively restrictive of users in their opportunities to participate in the digital social sphere, their sense of autonomy, their identity, dignity and wellbeing (cf. Jane, 2017a). Systematic campaigns of harassment, as in the \#GamerGate debate, see coordinated attacks launched on female users who are 'particularly visible' in specific internet communities (cf. Eickelmann, 2017). Jane perceives the existence of a gendered 'digital divide' (cf. 2017b).

I wish to propose an understanding of hate practices in this context as political practices systematically related to the devaluation of the female. The concept of the political in this understanding cannot be reduced to questions of government; it draws much more on active and influential participation in the social sphere (cf. Celikates \& Gosepath, 2013). Such an approach encompasses two key aspects: First, it identifies hate speech not as a random, individual phenomenon, but rather as fed by socially established gendered orders and the misogyny enshrined in them. Second, the political nature of the practices examined here relates to their revolving around a struggle to assert public spheres and visibility and ultimately a discursive struggle to assert truth. In the discriminatory invocation (see section below), the user attacked experiences a de-rationalisation and a loss of authority through gendering and sexualisation; this denormalises women's participation in digital public spheres and beyond, mainly due to its restriction of spaces for self-definition and autonomous action. We may also perceive this de-normalisation of participation as a latent strategy of disempowerment of women, and specifically of women who identify as feminists or queer feminists. In its disruption of the idea of femininity, a 
feminist and implicitly queer critique of identity thus works on the three levels of normalisation, empowerment and deconstruction, which will be important later on in my proposal of a form of media education that responds to the phenomenon of hate speech on a range of levels.

\section{The Negativity of the Medium: Representation Is (Not) THE Problem}

Representation is at the heart of media. One illustration of this which is particularly pertinent to matters of sexism is the so-called Bechdel test, or "The Rule", which originated from the comic strip Dykes to Watch Out For by Alison Bechdel (cf. 1985). Two protagonists of the comic talk about the quality of cinematic experience and the question of when it is worthwhile for them to go to the cinema: "I only go to a movie if it satisfies three basic requirements. One, it has to have at least two women in it... who, two, talk to each other about, three, something besides a man." 5 Until just five years ago, about $90 \%$ of the films made in Hollywood failed the test; the situation is currently changing. ${ }^{6}$ The test is of interest to this discussion because, in spite of its charmingly pragmatic productivity, its ability to easily illustrate the problem of representation, and thus its heuristic problematisation of visibilities and gendered orders, it, or the critique of representation implicit in it, lacks an essential moment of mediality. This type of critique of representation implies that there are 'correct' forms (or quantities) of representation and undertakes a simplification and a problematic naturalisation of the relationship between sign and signified. Mersch (2006), however, considers the definition of representation as 'successful' to be fundamentally problematic: "There are media because there is alterity. Otherness means an 'other' that initially refuses access, that needs a third party to guarantee its mediation, its symbolisation, storage, transmission or communication" (ibid.).

This points to the necessity of fundamental reflection on the constitutive difference between sign and signified and thus on the relationship between representation in media and what is represented, a relationship which, as I will now discuss using terms proposed by Theodor W. Adorno, appears essentially characterised by fragility. In Adorno's view, critique forms itself as a relationship of 'non-identity'. In founding the idea of the "the subject-object dichotomy" (Adorno, 2004, p. 6) he articulates a questioning of the "gesture of domination through identification" 
(Schäfer, 2004, p. 92) and assumes that designations (as practices of signifying), as appropriations by a symbolic order, always already represent a violent act. Adorno assumes that neither things nor the subject's self can be transparent to the subject. The I, in Adorno's terms, can never be the object of its own comprehensive knowledge; a term can never mean the object in itself nor can it be appropriated through understanding. Schäfer observes: "In contrast to such thinking that aims at conceptual and technical control over the world, that assumes that the world has to submit to subjective knowledge, Adorno's counter-perspective emphasises the 'primacy of the object'" (ibid.). Adorno's dialectic thus aims at reflecting on the contradictory circumstance that the object can never be identical with the concept it is identified with (ibid.), but is always more, means more, is - to speak with Laclau et al. (2012) —overdetermined. ${ }^{7}$ In Schäfer's view, Adorno illuminates in this way the "resistant nature of the object, its enigmatic character which eludes any identifying ordinance [Verfügung]" (Schäfer, 2019, p. 119), which implicates the possibility of education. "In this context, this experience of one's own self [which emerges from it, B.H.] is that of the failure of a subject figure exerting control" (ibid.). Drawing on Adorno, we could comprehend the fundamental, characteristic property of media as a "disturbance" (Schäfer \& Thompson, 2010, p. 141) which embodies in a fundamental manner the relationship of the subject to itself and to the world. What the medium, the text, the image shows (indeed generates) is always simultaneously incomplete and more than what is shown. Representation thus never leads to a recognition of the object; the processes of representation and reception nevertheless remain productive, but, in terms of a theoretical formulation of the mediality of technical apparatuses, the effort to produce an adequate representation always fails. Mediality, as Mersch (2006) points out, appears fundamentally characterised by negativity. Following this view, and in light of a critique of representation, we might perceive the medium itself as a third party, a figure of alterity and also of negativity, that is always present, and in its presence erases itself. This may point the way analytically, opening up a concept of media (Mersch, 2006) by highlighting the constitutive 'media-tion' of sociality and subjectivity, which means, effectively, that there is no practice outside media. Likewise, the converse holds, in that practice taking place within a technical medium, such as internet communication, is always a practice of the social. This concept of mediality thus calls for research that does not exclude or overlook any aspect of the social and whose leading focus is not a specific object in the sense of a technical 
device, but rather a perspective on cultural practices. This understanding of media critique and analysis gives rise to a systematic approach whose chief concern is to formulate questions around these arrangements of technologies and cultural practices as they emerge, for example, in the phenomenon of online hate speech. To come full circle at the conclusion to this section, we might reflect that representation is not the sole category at the heart of media. Krämer puts it much more precisely-mediality can be understood as performativity (Krämer, 2002, p. 329).

\section{Approaches to Subjectivation}

Having discussed the problem of representation with the help of Adorno's critique of the assertion of identity, the section that follows will explore the phenomenon of sexist hate speech from the perspective of subjectivation, in order to identify the production of relationships with the self and with the world by hate speech in a context of the analysis of power. The subject as defined by Enlightenment and idealist thought appears to us as autonomous, sovereign and capable of reason (cf. Reckwitz, 2008, p. 75); a post-structuralist conception instead emphasises its fundamental decentrality (cf. Zima, 2000), pinpointing subjectivity as arising not from a core within the individual, but rather in a fundamental reference to another. Michel Foucault (2000, p. 240$)$ considers subjectivation in modernity to occur as a form of government in three forms of objectivation: "Forms of knowledge, power technologies and processes of self-formation" (Lemke, 2006, p. 269). By government, Foucault does not refer to the power of leadership invested in a sovereign, an autocratic authority, but rather to the decentralisation of leadership, controlled by a complex network of social forces and forms of knowledge (Pieper \& Gutiérrez Rodríguez, 2003 , p. 10), and to leadership of self-leadership. How we learn to lead ourselves is always closely linked to how we understand ourselves, and as whom; analytical observation in this context is primarily directed towards the moment of "self-deciphering" (Lemke, 2004, p. 161). This leading of ourselves is interconnected with being led: Subjectivation unfolds in a dual, dialectically interlocking movement of 'being called' and obeying the call, as outlined by Althusser:

I shall then suggest that ideology 'acts' or 'functions' in such a way that it 'recruits' subjects among the individuals (it recruits them all), or 'transforms' the individuals into subjects (it transforms them all) by that very 
precise operation which I have called interpellation or hailing, and which can be imagined along the lines of the most commonplace everyday police (or other) hailing: 'Hey, you there!' Assuming that the theoretical scene I have imagined takes place in the street, the hailed individual will turn round. By this mere 180-degree physical conversion, he becomes a subject. Why? Because he has recognized that the hail was 'really' addressed to him, and that 'it was really him who was hailed' (and not someone else). (Althusser, 2014, p. 264)

In Althusser's study Ideology and Ideological State Apparatuses, interpellation denotes a process in which ideology in the form of an address, the "Hey, you there!" to which the person called turns, makes individuals into subjects. Judith Butler takes up the concept of the Althusserian interpellation in noting the subject's dependence on the conditions of being that precede it, relating this dependence to an analysis of power relations: "Subjection" signifies the process of becoming subordinated by power as well as the process of becoming a subject. Whether by interpellation, in Althusser's sense, or by discursive productivity, in Foucault's, the subject is initiated through a primary submission to power (Butler, 1997, p. 2). To Butler, however, subjection/subjectivation does not happen without the moment of foundation, of inauguration into an non-establishable position (ibid., 2001, pp. 9-10).

In Excitable Speech (2006), Butler assumes, with reference to Austin and Althusser, that language is performative; that is, the hurtful power of insults arises because language has an effect beyond speaking in its quoting of social 'truths' and thus identifies the subjects thus addressed in a way that, first, misjudges them and, second, limits their power of action. The question of validity - that is, when something is considered hate speechis not amenable to a definitive answer. Rather, from a point of view drawing on the theory of performativity, I presuppose the incommensurable productivity of speaking and identify the key question in this regard as relating to the way in which speaking becomes productive.

In this context, we might denote the influence of acts of addressing/ hailing on relationships with the self and with the world as a point of connection between education theory and the theory of subjectivation. While both Ricken (1999) and Koller (2011), for example, propose a reading of the concept of subjectivation as an educational concept, we would consider it legitimate here to distinguish education in the sense of education and subjectivation as drawn from the thought of Foucault and Butler. 
Foucault's critique of modernity's techniques of individualisation traces the subject as an object measured in specific rationalities; Foucault describes the process of subjectivation as a dual movement of becoming in and subjugation to social norms. Butler further elaborates how this becoming/subjugation inscribes itself in the subject, forming the "trace of the sociality of the subject in the subject" (Bierbaum, 2004, p. 184). Neither Foucault nor Butler conceive of subjectivation-as-education as the outcome of conditions of oppression. They rather regard power and the subject as intertwined and not juxtaposed. In Butler's view, norms are precisely the authority that constitutes the subject-but again, they do not determine it. Education or self-education therefore cannot lead to selfliberation, since freedom can be understood as permanently embedded in power relations.

I intend now to bring the specific conditions of becoming a subject-in relation to gender orders - into view by empirically operationalising the dialectical relationship between self-techniques, invocations/addresses and figurations of knowledge via the concept of addressing proposed by Reh and Ricken (2012), which emphasises subjectivation's positioning effect. The authors understand a positioning as a dual relational event: first, a setting in relation to oneself, others and the world, initialised by the act of addressing, and second, a setting in relation to this setting-inrelation (cf. Reh \& Ricken, 2012, pp. 39): "Subjectivation therefore refers to that practical (and precisely not, or not simply, reflective) process of engagement with culturally presented subject forms in which the individual as a self makes itself as well as being made a self by others; this engagement encompasses both subjection to the social orders in force and transgressions of them, revealing both consolidations and shifts [in these orders]" (ibid., p. 40).

For the targets of sexist practices of addressing, subjectivation in this sense does not multiply their possibilities of signification, action or positioning, but instead brings the play of identities to a standstill and fixates these identities on an insurmountable otherness. The sexist-identifying interpellation produces positions by imposing onto individuals a knowledge (about themselves and others) that stems from a specific order of knowledge and suggests certain self-techniques while preventing others. Being addressed in a sexist way that violates my need for self-determination, I am required to relate to an order of knowledge that marginalises and subordinates me. 
In Reh's and Ricken's terms, the invocation/interpellation, the calling that calls upon the subject to position itself, is a specific practical act. Acts of addressing, such as insults, represent practices which establish a reference to a person linguistically and physically, through acts of being touched, being looked at, gestures, and so on. In so doing, they reproduce facets of social orders and the relativity of the participants in the address; the performative double movement that ensues acts both to suspend these participants' subject positions and to confer validity upon them while shifting them. Reh and Ricken propose a three-step heuristic that could empirically examine processes of subjectivation via practices of addressing and re-addressing. They first seek to identify the "normative horizons" (ibid., p. 44) within which acts of addressing acquire meaning and therefore validity; second, they interrogate the positioning, anticipation and setting of relations; and third, illuminate the emergent spaces of possibility, the possibilities of a second-degree putting-into-relation, so to speak, in which the subject interprets the positioning performed in the address (cf. ibid., pp. 44). In this way, they unfold a methodical approach to examining practices of addressing, which takes into account the entanglement of the interactional and discursive levels.

\section{Online Hate Speech as Subjectivation and the Challenges of Media Education}

The section that follows will provide an analytical view of online hate speech in reference to the theoretical framework outlined above, before proceeding to discuss the findings of this analysis and their significance for an attempt to rethink media education.

Research based on the theory of subjectivation as set out by Butler has formulated an interest in the conditions under which an individual becomes a subject. This perspective both takes account of social structures and acknowledges a concept of practices that emphasises not the intentionality of action (and thus the autonomy of the subject), but rather its performative effects. Proceeding from the idea of negativity in Adorno and the subsequent concept of the performativity of the medium, we identify the character of mediality not as an aspect of technological artefacts, but rather as a fundamental moment of thinking and speaking (cf. Bernardy, 2013, p. 113). Applying this insight to online hate speech alongside the framework of recognition theory, we find ourselves facing 
the question of the productivity of speaking on the internet, as explored through the concept of subjectivation earlier in the chapter. The approaches to the phenomenon mentioned here demonstrate that we cannot think pedagogically about these matters if we do not incorporate an analysis of power relations into our perspective.

In connection with media and subjectivation, Jörissen speaks, for example, of the "constitutivity of mediality for relationships with the self and with the world" (Jörissen, 2011, p. 12), thus assuming that relationships involving the self, such as those of the self to the world and to others, and their transformations are fundamentally characterised by the moment of mediality, emerging in the field of tension between representation and productivity. Considering power relations in the light of theories of subjectivation complements the concept of mediality in this context by seeking to identify fundamental limitations of the spaces of possibility in which transformations of relationships with the self and with the world can take place.

An analysis of hate speech founded on approaches to power relations would perceive it as the expression and initiation of multi-dimensional social processes of education-'education' being understood here not as a process of the imparting and acquisition of knowledge, but in the sense of a transformation of self- and world relations. Acts of hate speech demand a response to the addresses they make, while requiring subjects to relate to the confrontational address in a way that also makes them relate to the world as their social context. Hate speech already includes a certain interpretation of the social which it imposes on the addressed subject. Speaking functions in this context via the citation of a social order: the word "slut" or "bitch" only hurts when the addressee knows about its degrading meaning and the structures that produce that meaning. Put differently, being hurt by such an address is an experience of the implicit violence of being identified in the context of a hegemony of meanings. To reference Reh and Ricken (2012), the "normative horizons" (ibid., p. 44) within which acts of addressing acquire meaning and therefore validity produce a kind of positioning, an anticipation and setting of relations, which lead to the emergence of spaces of (im)possibility. 'Education' in this context means actively relating to the claims of truth implemented in hate speech articulations: the truth of the social which includes the truth of the inferiority of the person being addressed. Approaches to media education that reflect these aspects of interconnection between subjectivation and education through online hate speech transcend a normative concept of media 
literacy (which simply aims to delineate the right way of using a specific technology) and prompt their recognition as political education. The specificity of sexist violence in social media in contrast to 'analogue' violence lies in the peculiarities of technological communication and the cultural practices emerging from them: the blurring of boundaries between asynchronicity and synchronicity of communication, the physical absence and (usually) anonymity of the perpetrator, the possibility of duplication and dissemination of data and of the initiation of hate campaigns, and the difficult traceability and confusion of routes and spaces communication on the internet. In the digital world, the public sphere unfolds across heterogeneous contexts, which may protect the perpetrators and increase the exposure of those affected. Understanding of and reflection upon these facets of violent online sexism may cast light on the nature of the apparently personal (of the hate-speech insult) as political.

In the context of this investigation, the concept of mediality refers to the field of tension between representation/mediation and the contingent production of meaning as attributable not solely to the so-called media, but to every materiality or phenomenon that intervenes in the social in this way (representing, and simultaneously rupturing its productivity in its representativeness). Elsewhere, I have proposed linking this concept with Butler's notion of the performative (cf. Hoffarth, 2009): speaking of the performativity of (mass) media makes it possible to perceive at their potentially deconstructive productivity. Digital media place the interactive action of the user at their centre and thus add the practice of inscribing to the practice of (productive) reading of media text as identified in earlier work from a cultural studies perspective. Led by this insight, we can observe that the users of online media communicatively shape the digital space. The medium's tendency to disappear in communication-its negativity-, which contributes to the assertion of representation as an unboken relationship between sign and signified, shores up the power of the violation inherent in hate speech. "Due to their technical-symbolic constitution, media architectures, in comparison to material settings, provide more variable, more dynamic, often more complex and, not least, often significantly novel variants of such 'performative' structures, which are accordingly accompanied by new potential for reflection" (Jörissen, 2011, p. 12) and, I would add, new potential for instances of violation.

The constitutively violent nature of the acts of addressing in sexist hate speech consists not only in the hurtful invocation, not only in the use of the insult itself, but also in the quasi-dual performativity of the invocation, 
in which the addressee is called upon to relate to the insult, to interpret it. This means that a concept of media education with the capacity to lay bare these consequences for subjectivation would need to take into account the representational ruptures in the media lives of those we wish to engage in this education. Jörissen's proposal is to incorporate the concept of consciousness or awareness of mediality into the conception of media education (Jörissen, 2011, p. 72). The development of this type of mediality awareness would possess a multi-faceted pertinence both to those exposed to sexist violations and to those who inflict these injuries. Measures aimed at preventing violent behaviour on the internet should address the latter in particular, rather than primarily seeking to limit young female users' scope of action in response to 'what might happen' to them. This concept of media education should also include political strategies drawing on antidiscrimination pedagogy, focusing on empowerment alongside reflection on privilege.

A useful concept for illuminating the strain on an approach to media education motivated by social and subject theory and attempting to address discriminatory structures is that of the "trilemma of inclusion" put forward by Mai-Anh Boger (2019), which consists in three dilemmas between the concepts of deconstruction, normalisation and empowerment, which it defines as constitutive moments of inclusion and which I linked to the phenomenon of hate speech above. Only two of these concepts can ever 'go' together, while the third must logically be excludedand yet all three constitute the practice of inclusion which we perceive here as a productive idea for political education and a critique of exclusion. While empowerment strategies function at both an essentialist and an individual level, strategies of normalisation, resting on an assumption of integration of someone into an assumingly normal assemblage, pursue the goal of participation in collective normalities. Deconstruction, finally, takes place in the form of analysis and critique of these normalities and essentialisations. ${ }^{8}$ A media education inspired by subjectivation theory, then, would aim to critique both social and technological structures alongside practices of representation. The challenge regarding the trilemma especially consists of analysing the meanings of normalisation, empowerment and deconstruction, that is, the desire for identity, empowerment and non-identity, in their various combinations in relation to social hegemonies such as gender, race and class, and of taking these meanings into account when designing media-education. At the same time, this pedagogy would need to consider the contingency of subjectivation and 
education as transformations of relationships with the self and with the world. Media education, in this sense, means using the productive tension in the trilemma to analytically examine and pedagogically work with transformations in individuals, institutions, and power relations in order to prevent hate speech-related violations on the internet.

\section{Notes}

1. Most quotations were originally published in German. All translations of these quotations were provided by the author.

2. Bourdieu did not have digital media in mind when he adopted the concept of doxa from Greek philosophy (cf. Fröhlich \& Rehbein, 2008, p. 79). The principal facet of the concept, as used by Bourdieu, that meets a crucial moment of digital media is its compatibility with postmodern conditions and its becoming 'natural' or normal and thus self-evident in its everyday use.

3. Cf., for example, Wischmann, 2018, on the German discourse on Bildung as education.

4. What follows will use the concept of 'education' to mark processes of transformation of self- and self/world relations (in contrast to practices of parenting or processes of socialisation and in contrast to education as pedagogy).

5. Alison Bechdel, ,The Rule', Dykes to Watch Out For, https://dykestowatchoutfor.com/wp-content/uploads/2014/05/The-Rule-cleaned-up.jpg, 19.05.2020.

6. https://bechdeltest.com/, 20.02.2020.

7. Bernardy points out that it is not necessarily contradictory to suggest an argumentative proximity between Adorno's concept of the non-identical and the deconstructivist idea of mediality (Bernardy, 2013, p. 113).

8. In terms of the theory of science, the concept is simultaneously a provocative and integrative project, in that it takes up divergent, even contradictory, theories and thus challenges scientific thinking and argumentation at various levels.

\section{REFERENCES}

Adorno, T. W. (2004). Negative dialectics. Taylor \& Francis e-Library.

Althusser, L. (2014). On the reproduction of capitalism: Ideology and ideological state apparatuses. Verso.

Amundsen, R. (2019). "Kind of like making porn of yourself": Understanding sexting through pornography. Feminist Media Studies, 19(4), 479-494.

Bedor, E. (2015). Sexting panic: Rethinking criminalization, privacy, and consent. Feminist Media Studies, 15(6), 1065-1066. 
Bernardy, J. (2013). Formen und Figuren literarischer Artikulation bei Foucault und Wittgenstein. In S. Niklas \& M. Roussel (Eds.), Morphomata: Vol. 11. Formen der Artikulation. Philosophische Beiträge zu einem kulturwissenschaftlichen Grundbegriff (pp. 109-141). Fink.

Bertelsmann Stiftung. (2019). Monitor Digitale Bildung: Berufliche Ausbildung im digitalen Zeitalter.

Bierbaum, H. (2004). Kritische Theorien des Subjekts (und) der Bildung: Foucault/Butler und Heydorn/Koneffke zwischen Differenz und Annäherung. In L. Pongratz, W. Nieke, \& J. Masschelein (Eds.), Schriftenreihe der Kommission Bildungs- und Erziehungsphilosophie der DGfE. Kritik der Pädagogik - Pädagogik als Kritik (pp. 180-199). Leske u. Budrich.

Boger, M.-A. (2019). Theorien der Inklusion: Die Theorie der trilemmatischen Inklusion zum Mitdenken (1. Auflage). Münster: Edition Assemblage.

Butler, J. (1997). The psychic life of power: Theories in subjection. Stanford University Press.

Butler, J. (2001). Psyche der Macht: Das Subjekt der Unterwerfung (1st ed.). Gender studies: $1744=$ n.F. 744. Frankfurt am Main: Suhrkamp.

Butler, J. (2006). Hass spricht: Zur Politik des Performativen. Suhrkamp.

Capurro, R. (2017). Homo Digitalis. Springer Fachmedien Wiesbaden.

Celikates, R., \& Gosepath, S. (2013). Politische Philosophie. Reclams UniversalBibliothek: Vol. 18473. Reclam.

Dengel, A. (2018). Digitale Bildung: ein interdisziplinäres Verständnis zwischen Medienpädagogik und Informatik. MedienPädagogik: Zeitschrift für Theorie und Praxis der Medienbildung, 33(0), 11-26. https://www.medienpaed.com/ article/view/558

Deuber-Mankowsky, A. (2007). Praktiken der Illusion: Kant, Nietzsche, Cohen, Benjamin bis Donna J. Haraway. Vorwerk 8.

Döring, N. (2014). Warum Sexting unter Jugendlichen (k)ein Problem ist. Online verfügbar unter. https://www.medienbewusst.de/handy/20140729/warumsexting-unter-jugendlichen-kein-problem-ist.html\#more-36290, last viewed 25.02.2020.

Döring, N., \& Mohseni, M. R. (2018). Male dominance and sexism on YouTube: results of three content analyses. Feminist Media Studies, 19(4), 512-524.

Eickelmann, J. (2017). Hate Speech und Verletzbarkeit im digitalen Zeitalter: Phänomene mediatisierter Missachtung aus Perspektive der Gender Media Studies. Transcript Verlag.

Foucault, M. (2000). Die Gouvernementalität. In U. Bröckling, S. Krasmann, \& T. Lemke (Eds.), Gouvernementalität der Gegenwart. Studien zur Ökonomisierung des Sozialen (pp. 41-67). Suhrkamp.

Fröhlich, G., \& Rehbein, B. (Eds.). (2008). Bourdieu-Handbuch: Leben - Werk Wirkung. Metzler, J B.

Gesellschaft für Medienpädagogik und Kommunikationskultur in der Bundesrepublik Deutschland e. V. (GMK). (2013). Medienkompetenzförderung 
für Kinder und Jugendliche. http://medienkompetenzbericht.de/pdf/ Medienkompetenzfoerderung_fuer_Kinder_und_Jugendliche.pdf

Hoffarth, B. (2009). Performativität als medienpädagogische Perspektive. Wiederholung und Verschiebung von Macht und Widerstand. Bielefeld: Transcript.

Iske, S. (2014). Medienbildung. https://content-select.com/de/portal/media/ view/53bcf17b-0408-4cf2-937b-1bd22efc1343

Jane, E. A. (2017a). 'Dude ... stop the spread': antagonism, agonism, and \#manspreading on social media. International Journal of Cultural Studies, $20(5), 459-475$.

Jane, E. A. (2017b). Gendered Cyberhate: A New Digital Divide? In Massimo Ragnedda \& Glenn W. Muschert (Eds.), Theorizing Digital Divides (pp. 158-198). Oxon: Routledge.

Jörissen, B. (2011). Medialität und Subjektivation.: Strukturale Medienbildung unter besonderer Berücksichtigung einer Historischen Anthropologie des Subjekts. Habilitationsschrift, Universität Magdeburg, Magdeburg.

Jörissen, B. (2014). Digitale Medialität. In C. Wulf \& J. Zirfas (Eds.), Handbuch Pädagogische Anthropologie (pp. 503-513). Springer.

Kaspar, K., Gräßer, L., \& Riff, A. (2017). Schriftenreihe zur digitalen Gesellschaft NRW: Band 4. Online Hate Speech: Perspektiven anf eine neue Form des Hasses. kopaed VerlagsGmbH.

Kerres, M. (2018). Mediendidaktik: Konzeption und Entwicklung digitaler Lernangebote.

Koller, H.-C. (2011). Bildung anders denken: Eine Einfübrung in die Theorie transformatorischer Bildungsprozesse. Pädagogik. KOHLHAMMER.

Krämer, S. (2002). Sprache - Stimme - Schrift. In U. Wirth (Ed.), Performanz. Zwischen Sprachphilosophie und Kulturwissenschaften (pp. 323-346). Suhrkamp.

Laclau, E., Mouffe, C., \& Hintz, M. (2012). Hegemonie und radikale Demokratie: Zur Dekonstruktion des Marxismus. Passagen Philosophie. Passagen Verlag.

Lemke, T. (2004). Test. In U. Bröckling, S. Krasmann, \& T. Lemke (Eds.), Glossar der Gegenwart (1st ed., pp. 263-271). Suhrkamp.

Lemke, T. (2006). Die politische Theorie der Gouvernementalität: Michel Foucault. In A. Brodocz \& G. S. Schaal (Eds.), UTB für Wissenschaft: Uni-Taschenbücher:... Politische Theorien der Gegenwart. Eine Einführung (2nd ed.). Budrich.

Lumsden, K., \& Morgan, H. (2017). Media framing of trolling and online abuse: Silencing strategies, symbolic violence, and victim blaming. Feminist Media Studies, 17(6), 926-940.

Mersch, D. (2006). Mediale Paradoxa. Zum Verbältnis von Kunst und Medien.: Einleitung in eine negative Medienphilosophie. http://www.sicetnon.org/ index.php/sic/article/view/115/130

Mitgutsch, K. (2009). Medienkompetenz weitergedacht: Über die Responsivität medialer Erfahrungen. In R. Kubac, C. Rabl, \& E. Sattler (Eds.), Weitermachen? Einsätze theoretischer Erziehungswissenschaft (pp. 194-207). Königshausen \& Neumann. 
Pieper, M., \& Gutiérrez Rodríguez, E. (Eds.). (2003). Gouvernementalität: Ein sozialwissenschaftliches Konzept in Anschluss an Foucault. Campus-Verl.

Reckwitz, A. (2008). Subjekt/Identität. In S. Moebius \& A. Reckwitz (Eds.), Poststrukturalistische Sozialwissenschaften (pp. 75-91). Suhrkamp.

Reh, S., \& Ricken, N. (2012). Das Konzept der Adressierung: Zur Methodologie einer qualitativ-empirischen Erforschung von Subjektivation. In I. Miethe \& H.-R. Müller (Eds.), Qualitative Bildungsforschung und Bildungstheorie (pp. 35-56). Budrich.

Ricken, N. (1999). Subjektivität und Kontingenz: Markierungen im pädagogischen Diskurs. Epistemata. Reibe Philosophie: Bd. 249. Königshausen \& Neumann.

Schäfer, A. (2004). Theodor W. Adorno: Ein pädagogisches Porträt. Beltz.

Schäfer, A. (2019). Bildung und/als Subjektivierung: Annäherung an ein schwieriges Verhältnis. In N. Ricken, R. Casale, \& C. Thompson (Eds.), Schriftenreihe der DGfE-Kommission Bildungs- und Erziehungsphilosophie. Subjektivierung. Erziehungswissenschaftliche Theorieperspektiven (pp. 119-136). Beltz Juventa.

Schäfer, A., \& Thompson, C. (2010). Negative Dialektik. In T. W. Adorno (Ed.), Schlüsselwerke der Identitätsforschung (pp. 141-159).

Sesink, W. (2014). Eine kritische Bildungstheorie der Medien. In W. Marotzki \& N. Meder (Eds.), Medienbildung und Gesellschaft: Vol. 27. Perspektiven der Medienbildung (pp. 11-44). Imprint: Springer VS.

Wischmann, A. (2018). The absence of 'race' in German discourses on Bildung. Rethinking Bildung with critical race theory. Race Ethnicity and Education, 21(4), 471-485.

Zima, P. V. (2000). Theorie des Subjekts: Subjektivität und Identität zwischen Moderne und Postmoderne. Francke.

Open Access This chapter is licensed under the terms of the Creative Commons Attribution 4.0 International License (http://creativecommons.org/licenses/ by $/ 4.0 /$ ), which permits use, sharing, adaptation, distribution and reproduction in any medium or format, as long as you give appropriate credit to the original author(s) and the source, provide a link to the Creative Commons licence and indicate if changes were made.

The images or other third party material in this chapter are included in the chapter's Creative Commons licence, unless indicated otherwise in a credit line to the material. If material is not included in the chapter's Creative Commons licence and your intended use is not permitted by statutory regulation or exceeds the permitted use, you will need to obtain permission directly from the copyright holder.

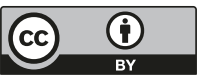

